\title{
Effect of Di-ethyl aminoethyl (DEAE) Dextran on the infectivity titre of sheep pox virus in-vitro and in-vivo
}

\author{
Olfat E. Nakhla*, Namaa A. Mohamed, Manal Awad, Mervat M. Ali \\ Veterinary Serum and Vaccine Research Institute, Abbasia, Cairo, Egypt.
}

\begin{abstract}
The effect of diethyl aminoethyl (DEAE) dextran on the infectivity titre of sheep pox virus (SPV) was studied with different concentrations $(25,50,75,100 \mu \mathrm{g} / \mathrm{ml})$ of DEAE-dextran on Vero cell culture. It was found that 25 and $50 \mu \mathrm{g} / \mathrm{ml}$ were not toxic. The same concentrations were used with sheep pox virus inoculum showing that the best virus titre $\left(10^{6.3} \mathrm{TCID}_{50} / \mathrm{ml}\right)$ reached with the use of $25 \mu \mathrm{g} / \mathrm{ml}$ DEAE-dextran after 10 passages. The enhanced viral fluid was tested in-vivo, by vaccination of susceptible lambs and challenge of them with the virulent sheep pox virus. These lambs showed complete protection against the disease. The SP neutralizing antibody indices (NI) were estimated in the collected serum samples post vaccination and challenge; confirmed that $25 \mu \mathrm{g}$ of DEAE-dextran/ml virus-inoculum induced an increase in neutralizing antibodies in comparison with those induced by currently used sheep pox vaccine.
\end{abstract}

Pox viral diseases affect most animal species and are of considerable economic importance in many regions of the world. Sheep pox disease causes severe financial loss in the international trade in animals and animal productivity, lower quality of wool and leather with death of unweaned lambs (Oguzoglu et al., 2006).

Sheep pox disease is characterized by fever, generalized papules or nodules, vesicles, internal lesions (partially in the lungs) and death (OIE, 2004).

Vaccination with the attenuated live sheep pox virus vaccine is the only mean for controlling this disease through stimulating the immune system of the susceptible lambs to produce antibodies against sheep pox virus (SPV) (Ivanyushchenkov et al., 1990). The enhancement of viral infectivity in cell culture systems by DEAE-dextran was well documented for a number of viruses (Sasaki et al., 1981; Soad, 1986; Zeneib, 2006; Bassiouny, 2007).

So, the present study was conducted in a trial to increase the infectivity titre of the SPV using DEAE-dextran, to obtain a maximum titre of the virus in cell culture and consequently allowing massive production of the vaccine with possibility of cost reduction.

\section{Materials and methods}

Animals. Nine susceptible Balady lambs about 4 months old not vaccinated against sheep pox disease and their sera were tested to prove that they are free from antibodies against SPV. They were used for potency and challenge test.

Sheep pox virus (SPV). SPV was kindly supplied by Pox Vaccine Research Dept.,
Veterinary Serum and Vaccine Research Institute, Abbasia, Cairo (VSVRI). It has a titre of $10^{5.8} \mathrm{TCID}_{50} / \mathrm{ml}$. It was used with different concentrations of DEAE-Dextran for vaccine preparation.

Virulent sheep pox virus. Virulent SPV (Egyptian strain) was obtained from Pox Dept., Veterinary Serum and Vaccine Research Institute, Abbasia, Cairo, Abbasia, Cairo. It was used for challenge test of vaccinated lambs.

Sheep pox vaccine. Living attenuated sheep pox virus vaccine was kindly obtained from Veterinary Serum and Vaccine Research Institute, Abbasia, Cairo, Pox Vaccine Research Dept. It has a titre of $10^{5.5} \mathrm{TCID}_{50} / \mathrm{ml}$.

Cell culture. African green monkey kidney cell line (Vero) was subcultured and maintained at Pox Vaccine Research Dept., VSVRI. Vero cells were used for preparation of SP vaccine and virus neutralization test.

Diethyl aminoethyl (DEAE) dextran. It was obtained from Formerly ICN Biomedical Inc. as DEAE powder form. Different stock solutions of DEAE-dextran were prepared by dissolving 25 , 50,75 and $100 \mathrm{mg}$ in $100 \mathrm{ml}$ (for each concentration) of $0.25 \mathrm{M}$ Tris-HCl buffer at $\mathrm{pH}$ 8.2. These solutions were sterilized by autoclaving and their $\mathrm{pH}$ was measured to be 7.6-7.8 and kept at room temperature until used according to Anderson et al., (1971).

Cytotoxic effect of DEAE-dextran on Vero cell culture. Different concentrations of DEAEdextran $(25,50,75,100 \mu \mathrm{g} / \mathrm{ml})$ were added to the growth media of Vero cell culture to determine the optimum concentration that can be

\footnotetext{
* Corresponding author. Tel.: +202 3424406;

Fax: +202 3428321

E-mail address: svri@idsc.gov.eg

(M. H. Khodeir)
} 
used without toxic effect on the cell culture according to Saber et al., (1984).

The effect of DEAE-dextran concentrations on propagation and titration of SPV. Vero cells were infected with SPV without adding DEAE-dextran and other cells were infected with SPV and DEAE-dextran at different concentrations ( 25 and $50 \mu \mathrm{g} / \mathrm{ml}$ ). Virus titration was applied according to Virology A Laboratory Manual (1992).

Potency and challenge tests. Three groups of susceptible lambs were used, each of which consisted of 3 animals (groups I, II and III). Group (I) was vaccinated with the field dose of the currently used SPV vaccine $\left(10^{3}\right.$ $\mathrm{TCID}_{50} /$ animal), $0.5 \mathrm{ml}$ injected intradermally (I/D) in the ventral aspect of the tail. Group (II) was vaccinated with the enhanced SPV vaccine with $25 \mu \mathrm{g} / \mathrm{ml}$ DEAE-dextran after adjusted to the titer of the required field dose, and group III was kept as non-vaccinated controls. Lambs were intradermally injected four weeks post vaccination with $0.5 \mathrm{ml}$ (100 virus particles) of the virulent sheep pox virus in the ventral aspect of the tail.

Serum samples. Serum samples were collected from vaccinated and unvaccinated control lambs post vaccination and challenge at weekly intervals for 6 weeks.

Virus neutralization Test (SNT). Virus neutralization test was used for detection of sheep pox virus neutralizing antibodies for all tested lambs and calculated with neutralizing indices according to Martin et al., (1975).

\section{Results and Discussion}

Live vaccines give long lasting immune response against most or all viral antigens. This immune response depends on the replication of the virus to give large antigenic dose and induce a balanced response (Whitton and Oldstone, 1996). The present work studied the enhancement of infectivity titre of live attenuated sheep pox virus vaccine using DEAE-dextran. Different concentrations of DEAE-dextran (25, 50,75 and $100 \mu \mathrm{g} / \mathrm{ml}$ ) were used in media maintaining Vero cell line. The obtained results showed that the cells maintained with the concentrations 25 and $50 \mu \mathrm{g} / \mathrm{ml}$ had no harmful cytotoxic effect, while 75 and $100 \mu \mathrm{g} / \mathrm{ml}$ concentrations were completely toxic, so both of them were excluded which is agreed with the findings of (Zeneib, 2006).

The sheep pox virus was mixed with DEAEdextran solution in a final concentration of 25 and $50 \mu \mathrm{g} / \mathrm{ml}$ inoculum and inoculated on Vero cell monolayers for serial passages and the virus titre was estimated for each passage. The results recorded in (Table 1) demonstrated that the virus infectivity reached titre $\left(10^{6.3}\right.$ and $10^{6.4}$ $\mathrm{TCID}_{50} / \mathrm{ml}$ ) respectively with the previous concentrations at $10^{\text {th }}$ passage which is higher than the titre of the SPV without DEAE-dextran $\left(10^{5.8} \mathrm{TCID}_{50} / \mathrm{ml}\right)$.

Thus, it is preferable to use the lowest concentration of DEAE-dextran $(25 \mu \mathrm{g} / \mathrm{ml})$ that giving a non significance difference lower virus titer $\left(10^{0.1} \mathrm{TCID}_{50} / \mathrm{ml}\right)$ than the concentration $50 \mu \mathrm{g} / \mathrm{ml}$, for economic purpose. These results indicated that DEAE-dextran as polycations enhanced the adsorption and uptake of the virus onto Vero cell line by creating a favourable ionic charge for virus attachment (Tessyu et al., 2004), or by inhibiting the extracellular and the intracellular strong nuclease activity which destroy the messenger RNA coded by viral DNA (Samira, 2001; Bassiouny, 2007) which reflect on increasing the virus infectivity.

The evaluation of the selected enhanced sheep pox virus with $25 \mu \mathrm{g} / \mathrm{ml}$ DEAE dextran in addition to the currently used vaccine was pursued by vaccination of susceptible lambs with both vaccines. The results showed that the vaccinated lambs of both groups resisted the challenge with the virulent sheep pox virus, which means that the antibodies produced from both vaccines were sufficient to protect animals from the infection.

Virus neutralization test on serum samples collected at different time intervals post vaccination and challenge was conducted to evaluate the humoral immune response. The obtained neutralizing indices showed that the neutralizing antibodies, titre in lambs vaccinated with enhanced sheep pox virus was (2.3 NI) but it was $(2.1 \mathrm{NI})$ in those vaccinated with the nonenhanced sheep pox vaccine 21 days post vaccination as recorded in (Table 2) and this increase referred to the immunostimulant effect of DEAE-dextran (Anderson et al., 1971; Soad, 1986).The study proved that DEAE-dextran enhanced sheep pox virus replication in Vero cells and the virus fluid prepared with it and injected with the field dose induce good immune response in vaccinated animals enabling them to resist the challenge. So, on the production scale, the prepared enhanced SPV titre could be adjusted to reach the same yield titre of the current prepared vaccine which can save time, labour and finance of the production of SPV vaccine. 
Table (1): Effect of different concentration of DEAE-dextran on the infectivity titre of sheep pox virus on Vero cell line.

\begin{tabular}{|c|c|c|c|}
\hline $\begin{array}{c}\text { Number of } \\
\text { passages }\end{array}$ & $\begin{array}{c}\text { SPV titre without DEAE- } \\
\text { dextran } \\
\left(\log 10 \mathrm{TCID}_{50} / \mathrm{ml}\right) \\
\end{array}$ & $\begin{array}{c}\text { SPV titre using } \\
25 \mu \mathrm{g} / \mathrm{ml} \text { of DEAE-dextran } \\
\left(\log 10 \text { TCID }_{50} / \mathrm{ml}\right)\end{array}$ & $\begin{array}{c}\text { SPV titre using } \\
50 \mu \mathrm{g} / \mathrm{ml} \text { of DEAE-dextran } \\
\left(\log 10 \mathrm{TCID}_{50} / \mathrm{ml}\right)\end{array}$ \\
\hline 1 & 5.8 & 5.8 & 5.7 \\
\hline 2 & 5.7 & 5.8 & 5.8 \\
\hline 3 & 5.6 & 5.9 & 5.9 \\
\hline 4 & 5.8 & 5.9 & 6.0 \\
\hline 5 & 5.9 & 6.0 & 6.1 \\
\hline 6 & 5.8 & 6.1 & 6.1 \\
\hline 7 & 5.8 & 6.2 & 6.2 \\
\hline 8 & 5.5 & 6.2 & 6.3 \\
\hline 9 & 5.7 & 6.3 & 6.4 \\
\hline 10 & 5.8 & 6.3 & 6.4 \\
\hline
\end{tabular}

Table (2): SPV neutralizing antibody index (NI).

\begin{tabular}{cccc}
\hline \multirow{2}{*}{ Weeks post vaccination } & \multicolumn{3}{c}{ Mean SP-NI } \\
\cline { 2 - 4 } & Group (I) & Group (II) & Group (III) \\
\hline 1 & 0.9 & 1.1 & 0.0 \\
3 & 1.5 & 1.8 & 0.0 \\
$4^{*}$ & 2.1 & 2.3 & 0.0 \\
5 & 2.0 & 2.3 & 0.0 \\
6 & 1.8 & 2.1 & 1.2 \\
\hline
\end{tabular}

Group (I): Lambs vaccinated with the currently used sheep pox vaccine

Group (II): Lambs vaccinated with the prepared sheep pox vaccine enhanced with $25 \mu \mathrm{g} / \mathrm{ml}$ DEAE-dextran

Group (III): Non-vaccinated controls lambs

* Challenge time with the virulent sheep pox virus

\section{References}

Anderson, E. C.; Master, R. C. and Mowat, G. N. (1971): Immune response of pigs of inactivated foot and mouth disease vaccines. Response to DEAE-dextran and saponin adjuvanted vaccines. Res. Vet. Sci., 12: 351-357.

Bassiouny, A. I. I. (2007): Trials for preparation of enhanced live attenuated camel pox vaccine. M.Sc. Thesis, Virology, Fac. Vet. Med., Cairo Univ., Egypt.

Cottral, G. E. (1978): Pox viruses. In Manual of Standardized Methods for Veterinary Microbiology, ed. G.E. Cottral Cornell Univ. Press (Ithaca and London), pp. 273-291.

Ivanyushchenkov, V. N.; Kekukh, V. G. and Korebo, D. A. (1990): Innocuity and immunogenicity of a live attenuated sheep pox vaccine. Veterinarya, Moskova, 7: 2830.

Martin, W. B.; Ehran, M. and Onar, B. (1975): Studies on sheep pox vaccine, serum-virus neutralization tests. Pendix Veteriner Kontrol ve Arastirm Institusu Dergisi, 8 (1): 26-47.

Office International des Epizooties (OIE) (2004): Sheep pox and goat pox. Manual of Diagnostic Tests and Vaccines for Terrestrial Animals. Part 2, Sec. 2-1, 2.1.10. pp. 1-16.

Oguzoglu, T. C.; Alkan, F.; Ozkul, A.; Vural, S. A.; Gungor, A. B. and Burgu, I. (2006): A sheep pox virus outbreak in central Turkey in 2002: Isolation and identification of capripox virus ovis. Vet. Res. Comm.,
30: 965-971.

Saber, M.; Taha, M. and Mohsen, A. Y. (1984): Influence of DEAE-dextran on the yield of RVF virus propagated on different cell cultures system. Agri. Res., Rev., 62 (58): 158-165.

Samira S. T. (2001): Influence of DEAE-dextran on the yield of parainfluenza-3 (PI-3) virus propagated on different cell culture systems. Egypt. J. Agric. Res., 79 (1): 360-371.

Sasaki, K.; Furukawa, T. and Potkin, S. A. (1981): Enhancement of infectivity of cell free varicilla zoster virus with diethylaminoethyl-dectran. Proc. Soc. Exp. Biol. Med., USA, 166: 281-286.

Soad, M. S. (1986): Virological and immunological studies on fowl pox virus. Ph.D. Thesis, Poultry Dis., Fac. Vet. Med., Cairo Univ., Egypt.

Tessyu, Y.; Tasutomu, Y.; Miyuki, I. and Motohiko, O. (2004): Factors improving the propagation of Simkamia negevensis strain $\mathrm{Z}$ in cell culture. Jpn J. Infect., 57: 103106.

Virology A Laboratory Manual (1992): Florence G. Burleson, Thomas M. Chambers, Danny, L. Wiedberauk. Section 2 pp. 41-45, 58-62.

Whitton, J. L. and Oldstone, M. B. A. (1996): Fundamental Virology. Immune response to viruses, pp. 311-340.

Zeneib T. S. S. (2006): Effect of dextran on the infectivity titre of bovine ephemeral fever virus produced on different cell cultures. Minufiya. Vet. J., 4 (1): 189-194.

\begin{tabular}{|c|}
\hline 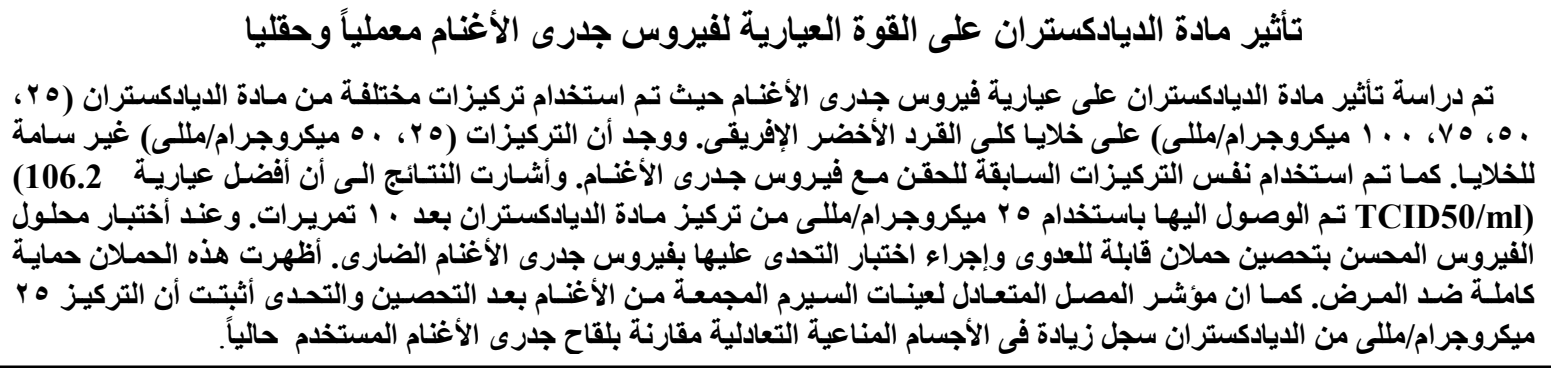 \\
\hline
\end{tabular}

